\title{
強圧延誘起へテロナノ組織がオーステナイト系ステンレス鋼の 力学特性に与える影響に関する結晶塑性シミュレーション
}

\author{
青柳 吉輝 $^{1)^{*}}$. 渡邊 千尋 ${ }^{2)} \cdot$ 小林 正和 $^{3)} \cdot$ 戸高 義一 ${ }^{3)} \cdot$ 三浦 博已 ${ }^{3)}$ \\ Crystal Plasticity Simulation on Effect of Heterogeneous-nanostructure Induced by Severe Cold-rolling \\ on Mechanical Properties of Austenitic Stainless Steel \\ Yoshiteru Aoyagi, Chihiro Watanabe, Masakazu Kobayashi, Yoshikazu Todaka and Hiromi Miura
}

Synopsis : Severe plastic deformation has attracted interests as one of the breakthrough procedures to improve various properties of metals and alloys. Recently, it has been revealed that heavy cold rolling of some kinds of austenitic stainless steels can cause ultrafine-grained structure comparable with those achieved by severe plastic deformation. Coarse initial grains were fragmented by deformation induced microstructure to develop heterogeneous nanostructure. Tensile strength of heterogeneous-nanostructured stainless steel exceeds $2 \mathrm{GPa}$. It is considered that high strength of heterogeneous-nanostructured metals is attributed to such peculiar microstructure with dispersed "eye-shaped twin domains". In this study, microstructural mechanisms and factors which contribute to macroscopic strength of heterogeneous-nanostructured austenitic stainless steel were evaluated on the basis of multiscale crystal plasticity simulation. Microstructure of heavily cold-rolled SUS316LN austenitic stainless steel was investigated by transmission electron microscopy, and stress-strain curves were attained by tensile tests. It was observed that microstructure of SUS316LN manufactured by $92 \%$ cold rolling was composed of deformation nano-twins, shear bands, and lamella structure. Evaluation of mechanical properties of heterogeneous-nanostructured SUS316LN was conducted using crystal plasticity finite element simulation considering microstructural information, such as dislocation density, crystal orientation, shape of grains, and dislocation sources. Information of microstructure obtained by electron backscatter diffraction, e.g. geometry of heterogeneous nanostructures and crystal orientation, were introduced to computational models for multiscale crystal plasticity simulation. It was revealed that deformation behavior depends on the tensile direction and the strength increases with the increase of volume fraction of twin domains as well as nano-twin and lamellar inter-spacings.

Key words: austenitic stainless; dislocation; crystal plasticity; heterogeneous-nanostructured metals, nano-twin; simulation.

\section{1. 緒言}

望ましい材料特性を得るために, 金属材料には合金化, 熱処理および表面処理などが行われている。しかし，近年 の材料加工においては, 高水準な材料特性が求められるだ けでなく, 環境, 資源打よびエネルギーなどへの配慮に対 する要求も高くなってきている。高度で多面的になる要求 に従来の材料開発法のみで応えていくのは困難になりつつ ある。そこで, 以上のような要求に同時に応えられる画期 的な方法として巨大ひずみ加工による結晶粒超微細化が 注目されている ${ }^{1-5)}$ 。巨大ひずみ加工を施した金属材料は 加工前の粗粒材と比較して優れた機械的特性を示すばかり でなく ${ }^{6-11)}$, 化学組成の変更打よび複雑な熱处理を必要と しないため環境, 資源打よびエネルギーの点においてもブ レイクスルーとなり得るとして期待が大きい。一方で, 巨
大ひずみ加工材料の特異な機械的特性は超微細結晶粒組 織に起因すると考えられるため, 巨視的機械的特性を発現 する微視的メカニズムの解明が重要である。近年では, 巨 大ひずみ加工を用いて, 結晶粒の均一な超微細化ではなく 階層的あるいは複合的に複雑な微細組織の導入による機械 的特性の向上が試みられている。積層欠陥エネルギーの低 い金属は, 塑性変形において転位の運動によるすべり変形 だけでなく変形双晶および積層欠陥の形成が可能である。 Morikawa ${ }^{12)}$ 打よびNakao and Miura ${ }^{13)}$ はオーステナイト 系ステンレス鋼に強ひずみまたは巨大ひずみ加工を施す と, 一部または全域に変形双晶を形成し, 非常に高い強度 を示すことを報告した。その中で，巨大ひずみ加工の一種 である多軸鍛造加工を施したSUS316オーステナイト系ス テンレス鋼の降伏応力は $2 \mathrm{GPa}$ 超えることが報告されて いる ${ }^{13)}$ 。オーステナイト系ステンレス鋼は耐食性扰よび加

2018年5月31日受付２018年7月17日受理（Received on May 31, 2018 ; Accepted on Jul. 17, 2018)

1) 東北大学大学院工学研究科ファインメカニクス専攻 (Department of Finemechanics, Tohoku University, 6-6-01 Aoba Aramaki Aoba-ku Sendai Miyagi 980-8579)

2) 金沢大学理工研究域機械工学系 (Division of Mechanical Engineering, Kanazawa University)

3) 豊橋技術科学大学機械工学系 (Department of Mechanical Engineering, Toyohashi University of Technology)

* Corresponding author : E-mail : aoyagi@tohoku.ac.jp

DOI : https://doi.org/10.2355/tetsutohagane.TETSU-2018-078 
工性が優れており広い分野で需要が大きいため, 化学組成 の変更を必要としない巨大ひずみ加工による高強度化が期 待される。また, 単純な結晶粒の微細化だけでなく変形双 晶誘起の微細組織に起因する高強度化のメカニズムの解明 は, 他の金属材料への応用も期待される。近年では, 双晶 による高強度化の研究が進んで打り ${ }^{15-18)}$, 冷間で単純強圧 延を施したオーステナイト系ステンレス鋼において圧延に よるラメラ組織, 変形双晶, そして, せん断帯を含む「へテ ロナノ組織」 ${ }^{19)}$ が形成し，巨大ひずみ加工によって作製さ れた超微細結晶粒材に匹敵する高強度化が達成されてい る。このへテロナノ組織に打ける変形挙動を評価すること で更なる高強度化が期待される。単純強圧延によるへテロ ナノ組織の発達と高強度化は, 巨大ひずみ加工では困難で あった大量生産や工業化に適しているだけではなく, 巨大 ひずみ加工材の機械的特性を凌ぐ可能性が報告され始め た ${ }^{13,14)}$ 。しかし，変形双晶を含む複合的な微細組織を有す る材料が特異な力学挙動を発現する微視的メカニズムはま だ十分に解明されていない。

そこで本研究では強圧延を施したオーステナイト系ス テンレス鋼の強度に影響を及ぼす微視的影響因子の解 明を目的として, まず, 強圧延誘起微細組織の形態や結 晶学的情報を明らかにするため, 単純冷間強圧延を施し たSUS316LN材に対する透過型電子顕微鏡（Transmission Electron Microscopy，TEM）による組織観察結果 ${ }^{20)}$ を示す。 また, 実験および解析で得られる応力ーひずみ線図を比較 して組織観察結果を考慮した解析手法がへテロナノ組織の 変形挙動を表現できることを示す。さらに, ヘテロナノ組 織がマクロな材料強度に及ぼす影響を検討するため, 引張 方向, ヘテロナノ組織を構成するそれぞれの組織の幾何学 的寸法打よび体積分率を疑似的に変更して有限要素解析 を行った。強圧延を施したSUS316LN材の変形双晶バンド 幅，小角粒界に囲まれたサブグレインの粒径打よびラメラ 間隔はナノオーダとなるため, 転位源を持たない粒が存在 する。このような粒では, 塑性変形は転位の粒界の通過, 粒界からの転位の発生あるいは発生した転位による新たな 転位源の活動などによって起こると考えられる。そこで本 研究では, 著者らが提案した転位源挙動を表現する結晶塑 性モデル211 を数值解析へ適用した。へテロナノ組織内の構 造を変更した場合の解析結果を比較し, 強度に影響を及ぼ す微細組織の評価を行うことで, へテロナノ組織を有する 材料の特異な力学挙動の発現メカニズムについて考察し た。

\section{2. 実験方法・結果}

本章では, 単純強圧延を施したオーステナイト系ステン レス鋼が有する微細組織を明らかにし, 有限要素解析に反 映させるため, 既報 ${ }^{20)} に て て$ 報告されているへテロナノ組
織の概要および力学特性を簡単に示す。本研究では, 厚さ $6.3 \mathrm{~mm}$ のオーステナイト系ステンレス鋼 SUS316LNの熱 間圧延板に対し, 厚さが $0.5 \mathrm{~mm}$ になるまで冷間圧延 (圧延 率約 $92 \%$ ）を施した試料に対する組織観察および力学特性 測定を行った。

\section{2・1 TEMによる組織観察}

$92 \%$ の冷間圧延を施したSUS3 16 LN 材に対し, 数值解析 で使用する微細組織の形態および結晶方位を測定した。測 定にはTEMを用い, 圧延方向 (Rolling Direction, RD), 圧 延面法線方向 (Normal Direction, ND) および圧延ロール方 向 (Transverse Direction, TD) から観察を行った。

Fig.1にTEMを用いてTDより観察した明視野像を示す。 組織は, Fig.1の中心部に観察されるNDに垂直な双晶境界 面を持つ変形双晶領域, 厹の周りを囲む領域に存在するせ ん断帯およびさらにその領域の外側の RD に伸長したラメ ラ状組織の3 種類の組織に分類できる。双晶領域中の双晶 面間隔 (双晶境界間隔) $d_{t}$ は $20 \pm 2 \mathrm{~nm}$, ラメラ境界間隔 $d_{l}$ は $100 \pm 20 \mathrm{~nm}$ およびせん断帯幅 $d_{s}$ は $90 \pm 20 \mathrm{~nm}$ であった。 Fig.1に拈ける領域 1 から領域4における電子回折パターン をFig.2に示す。いずれの領域においても $[0 \overline{1} 1]$ がTDとほ ぼ平行となっており, 変形双晶である領域 1 では双晶境界 (// (111)）がND面とほぼ平行となっていた。領域2（ラメ

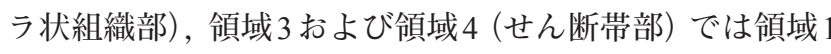
の双晶 1 の結晶方位に対して $[0 \overline{1} 1]$ を回転軸としてそれぞ れ $48.1^{\circ}, 50.6^{\circ}$ おび $39.2^{\circ}$ 回転した結晶方位が得られた。 電子回折パターンから $[0 \overline{1} 1]$ を回転軸とした $[111]$ のばら つきは領域 $2 て ゙ 10^{\circ}$, 領域 3 で $16^{\circ}$ および領域 4 で $25^{\circ}$ 程度で あり,ラメラ状組織およびせん断帯内が小角粒界に囲まれ ていることが確認された。

\section{$2 \cdot 2$ 引張試験による応力ーひずみ関係の測定}

ヘテロナノ組織を有する SUS316LN材の RD およびTD に対し引張試験を行い応力ーひずみ関係を測定した。Fig.3 に得られた応力ーひずみ線罒を示す。引張試験片ゲージ部 に貼付したひずみゲージで測定したヤング率は引張方向が

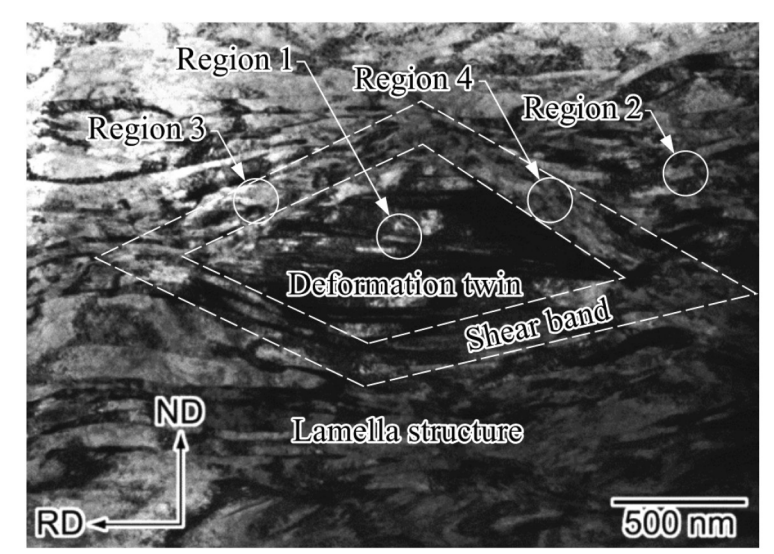

Fig. 1. TEM micrograph of severely cold-rolled SUS316LN stainless steel. Incident beam direction is parallel to TD. 


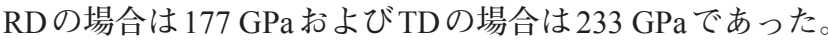
$0.2 \%$ 耐力は引張方向が RDの場合は $1411 \mathrm{MPa}$ 打よびTDの 場合は $1548 \mathrm{MPa}$ であった。いずれの值も，引張方向が TD の場合の方が RDの場合より大きくなる傾向を示した。

\section{3. マルチスケール結晶塑性モデル}

本研究では, 引張試験を想定し，著者らが提案したマル チスケール結晶塑性モデル ${ }^{21)}$ 用いた有限要素解析を行っ た。結晶塑性論における弾粘塑性構成式が次式のとおりて ある。

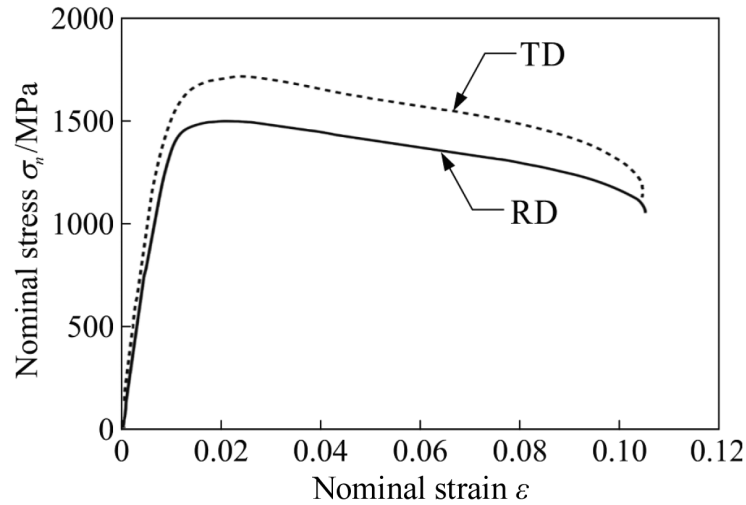

Fig. 3. Experimental stress-strain curves of a severely coldrolled SUS316LN stainless steel. Tensile axis is parallel to $\mathrm{RD}$ or $\mathrm{TD}$.

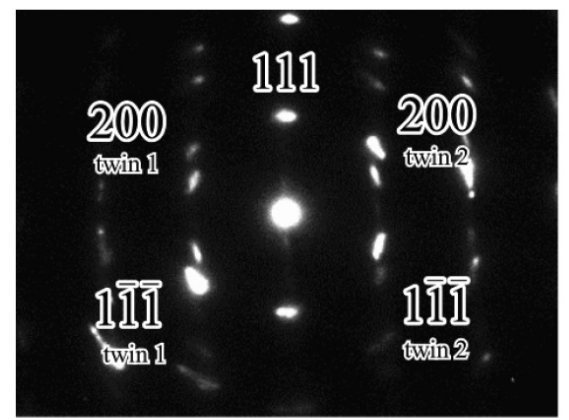

(a) Region 1

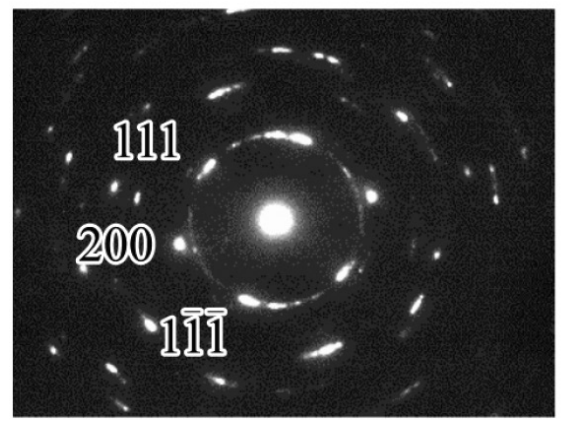

(c) Region 3

$$
\stackrel{\nabla}{\boldsymbol{T}}=\boldsymbol{C}^{\mathrm{e}}: \boldsymbol{D}-\boldsymbol{C}^{e}: \sum_{\alpha}\left(\boldsymbol{s}^{(\alpha)} \otimes \boldsymbol{m}^{(\alpha)}\right)_{S} \dot{\gamma}^{(\alpha)}
$$

ここで, $\stackrel{\nabla}{\boldsymbol{T}}$ は Cauchy応力の共回転速度, $\boldsymbol{C}^{e}$ は弾性係数テン ソル, $D$ は変形速度テンソル,$s^{(\alpha)}$ はすべり方向の単位べク トルおよび $\boldsymbol{m}^{(\alpha)}$ はすべり面の法線方向の単位べクトルであ る。すべり速度 $\dot{\gamma}^{(\alpha)}$ に対するひずみ速度依存型の硬化則と して，次式で表されるPan-Rice型のすべり速度硬化則 ${ }^{22}$ を 用いた。

$$
\dot{\gamma}^{(\alpha)}=\dot{\gamma}_{0}^{(\alpha)}\left(\frac{\tau^{(\alpha)}}{g^{(\alpha)}}\right)\left|\frac{\tau^{(\alpha)}}{g^{(\alpha)}}\right|^{\frac{1}{m}-1}
$$

ここで, $\dot{\gamma}_{0}^{(\alpha)}$ は参照すべり速度, $\tau^{(\alpha)}$ は分解せん断応力, $g^{(\alpha)}$ は流れ応力および $m$ はひずみ速度感度指数である。また, 流れ応力 $g^{(\alpha)}$ の発展式はすべり系の相互作用を考慮した硬 化係数 $h^{(\alpha \beta)}$ を用いて次式で表される。

$$
\dot{g}^{(\alpha)}=\sum_{\beta} h^{(\alpha \beta)}\left|\dot{\gamma}^{(\beta)}\right|
$$

ここで, $h^{(\alpha \beta)}$ はすべり系間の相互作用を表す硬化係数マト リクスである。流れ応力に転位密度の情報を考慮する場合 は多重すべり系に拡張された Bailey-Hirshの式 ${ }^{23)}$

$$
g^{(\alpha)}=\tau_{0}^{(\alpha)}+\sum_{\beta} \Omega^{(\alpha \beta)} a \mu \tilde{b} \sqrt{\rho_{d}^{(\beta)}}
$$

を適用する。ここで, $\tau_{0}{ }^{(\alpha)}$ は参照流れ応力, $\Omega^{(\alpha \beta)}$ は各すべり 系間の転位相互作用行列 ${ }^{23)}, a$ は 0.1 オーダの数值係数, $\mu$

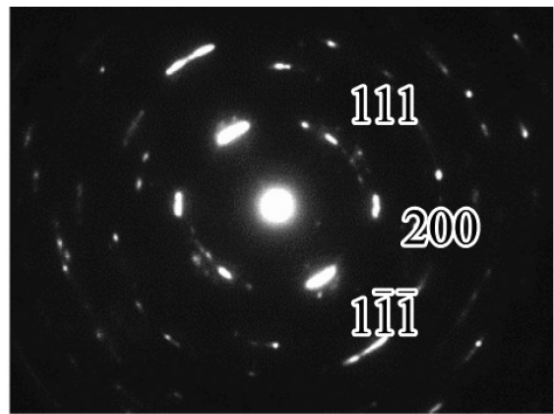

(b) Region 2

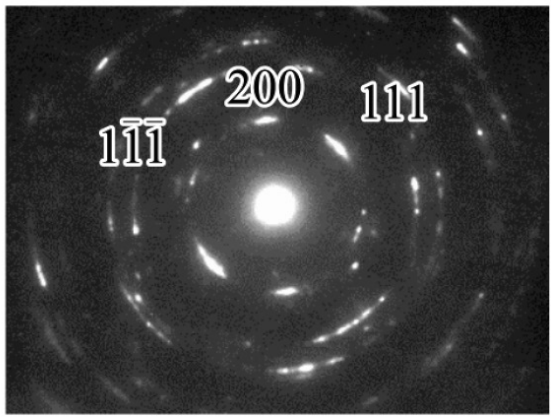

(d) Region 4

Fig. 2. Selected area diffraction patterns of severely cold-rolled SUS316LN stainless steel obtained from the regions depicted in Fig.1. 
は横弾性係数, $\widetilde{b}$ はBurgersべクトルの大きさおよび $\rho_{d}^{(\beta)}$ は すべり系 $\beta$ に蓄積された転位密度である。転位密度の定義 には, 著者らが提案した次式に示すすべり変形に伴う蓄積 転位密度 ${ }^{21)}$ を用いる。

$$
\dot{\rho}_{d}^{(\alpha)}=\left(1-k \rho_{d}^{(\alpha)}\right) \frac{r \rho_{f}}{\tilde{b}}\left|\dot{\gamma}^{(\alpha)}\right|
$$

ここで, $k$ は転位の対消滅率, $r$ は残留転位の平均長さおよ び $\rho_{f}$ は林立転位密度である。拡張Bailey-Hirshに時間微分 を施し，その結果に式 (5) を代入することによって，転位 密度に基づく硬化係数が次式のように求められる。

$$
h^{(\alpha \beta)}=\frac{a \mu r}{2} \Omega^{(\alpha \beta)} \frac{\rho_{f}}{\sqrt{\rho_{d}^{(\beta)}}}\left(1-k \rho_{d}^{(\beta)}\right) .
$$

超微細結晶粒材料やナノ双晶を有するへテロナノ材料は転 位がほとんど存在しない領域，すなわち転位密度が極めて 低い領域が存在する。このような領域では転位源が存在し ないために臨界分解せん断応力が完全結晶を想定した理想 せん断強度に近づくと考えられる。この場合，転位はまず 粒界から発生するか，他の粒で発生した転位が粒界を跨い で伝播し，それらの転位が新たな転位源を形成すると考え られる。したがって, 転位密度が低い場合, 臨界分解せん 断応力は転位密度だけでなく, 転位源の数および粒界にも 大きく影響を受ける。本解析では，転位源および転位源と しての粒界の情報を考慮して, 既報 ${ }^{21)}$ と同様に結晶塑性論 における流れ応力 $g^{(\alpha)}$ を次式のようにモデル化した。

$$
g^{(\alpha)}=\max \left\{\tau_{d}^{(\alpha)}, \min \left(\tau_{s}^{(\alpha)}, \tau_{m}^{(\alpha)}, \tau_{g}^{(\alpha)}\right)\right\}
$$

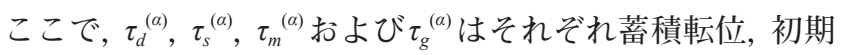
転位源, 可動転位打よび結晶粒界の存在に起因する流れ応 力である。式 (7) における $\tau_{d}^{(\alpha)}$ は拡張した Bailey-Hirshの式 を適用する。すなわち

$$
\tau_{d}^{(\alpha)}=\tau_{0}^{(\alpha)}+\sum_{\beta} \Omega^{(\alpha \beta)} a \mu \tilde{b} \sqrt{\rho_{d}^{(\beta)}}
$$

となる。式 (8) に打ける $\tau_{0}^{(\alpha)}$ は $\min \left(\tau_{s}^{(\alpha)}, \tau_{m}^{(\alpha)}, \tau_{g}^{(\alpha)}\right)$ に置き 換えることができるが, $\min \left(\tau_{s}^{(\alpha)}, \tau_{m}^{(\alpha)}, \tau_{g}^{(\alpha)}\right)$ が極めて小さ い場合には $g^{(\alpha)}$ が零に近づき，式 (2) で表されるすべり速 度が発散してしまうため計算が実行できない。そのため, 本解析では $\tau_{0}^{(\alpha)}$ を式中に残し, 数值解析の際には解析結果 に影響を与えない程度の小さい值を代入する。一方， $\tau_{s}^{(\alpha)}$, $\tau_{m}^{(\alpha)}$ および $\tau_{g}^{(\alpha)}$ はそれぞれ次式で与えられる，転位源となり 得る各サイトから転位を放出あるいは転位が運動する際の 分解せん断応力の值である。

$$
\tau_{s}^{(\alpha)}=-\frac{1}{2}\left(\tau_{P}-\tau_{F R}\right)+\tanh \left(c \frac{\rho_{s}^{(\alpha)}-\rho_{s c}}{\rho_{s r}}\right)+\frac{1}{2}\left(\tau_{P}+\tau_{F R}\right) \cdots
$$

$$
\begin{gathered}
\tau_{m}^{(\alpha)}=-\frac{1}{2}\left(\tau_{P}-\tau_{M D}\right)+\tanh \left(c \frac{\rho_{g n}^{(\alpha)}-\rho_{m r}}{\rho_{m r}}\right)+\frac{1}{2}\left(\tau_{P}+\tau_{M D}\right) \\
\tau_{g}^{(\alpha)}=-\frac{1}{2}\left(\tau_{P}-\tau_{G B}\right)+\tanh \left(c \frac{\phi_{g}^{(\alpha)}-\phi_{r}}{\phi_{r}}\right)+\frac{1}{2}\left(\tau_{P}+\tau_{G B}\right) \ldots \ldots . .
\end{gathered}
$$

ここで, $\tau_{P}$ は理想せん断強度, $\tau_{F R}$ はFrank-Read源が活動す るせん断応力, $c$ は数值パラメータ, $\rho_{s}^{(\alpha)}$ は転位源の転位密 度, $\rho_{s c}$ はFrank-Read源に関するしきい值， $\tau_{M D}$ は可動転位が 移動するせん断応力, $\rho_{g n}^{(\alpha)}$ は可動転位密度, $\rho_{m r}$ は可動転位 に関するしきい值， $\tau_{G B}$ は結晶粒界から転位が放出される のに必要なせん断応力, $\phi_{g}^{(\alpha)}$ は方位差パラメータおよび $\phi_{r}$ は方位差に関するしきい值である。式 (9) から式 (11) は 転位密度や方位差パラメータがしきい值を超える際の臨 界分解せん断応力の低下を表現する。理想せん断強度 $\tau_{P}$, Frank-Read源が活動するせん断応力 $\tau_{F R}$, 可動転位が移動す るせん断応力 $\tau_{M D}$, 転位源の転位密度 $\rho_{s}^{(\alpha)}$, 可動転位密度 $\rho_{g n}^{(\alpha)}$ および方位差パラメータ $\phi_{g}^{(\alpha)}$ はそれぞれ次式で表される。

$$
\begin{aligned}
& \tau_{P}=\frac{\mu \tilde{b}}{2 \pi h} \\
& \tau_{F R}=\frac{\mu \tilde{b}}{l} \\
& \tau_{M D}^{(\alpha)}=-\frac{1}{2}\left(\tau_{P N}-\tau_{G T}\right)+\tanh \left(c \frac{\phi_{g}^{(\alpha)}-\phi_{r}}{\phi_{r}}\right)+\frac{1}{2}\left(\tau_{P N}+\tau_{G T}\right) \\
& \rho_{s}^{(\alpha)}=e \rho_{d}^{(\alpha)} \\
& \rho_{g n}^{(\alpha)}=\left\|\rho_{g n}^{(\alpha)}\right\|=\left\|\frac{1}{\tilde{b}}\left(s^{(\alpha)} \otimes \boldsymbol{m}^{(\alpha)}\right) \times \nabla \gamma^{(\alpha)}\right\| \\
& \phi_{g}^{(\alpha)}=\left|\operatorname{curl} \boldsymbol{m}^{(\alpha)}\right|
\end{aligned}
$$

ここで, $h$ はすべり面間の距離, $l$ は転位源の大きさ $\tau_{P N}$ は Peierls-Nabarro 応力に基づくせん断応力, $\tau_{G T}$ は可動転位が 結晶粒界を飛び越えるのに必要なせん断応力, $e$ は転位密 度に対する転位源密度の割合に関する係数打よび $\rho_{g n}^{(\alpha)}$ GN 転位密度テンソル ${ }^{24)}$ である。式 (7) は, 塑性変形は最 も活動しやすい転位源 $\left(\tau_{s}^{(\alpha)}, \tau_{m}^{(\alpha)}\right.$ および $\left.\tau_{g}^{(\alpha)}\right)$ から開始する が, 蓄積転位が転位運動へ与える抵抗 $\left(\tau_{d}^{(\alpha)}\right)$ との大小関係 によって流れ応力が決定されることを示している。すなわ ち, 転位源が活動しやすい状態では流れ応力は蓄積転位に 支配され式 (4) と同様の挙動を示すが, 転位源が活動しに くい超微細粒材料やへテロナノ材料などでは転位源挙動が 降伏挙動を支配することを示す。

均一に近い連続分布を仮定して初期転位密度を設定する と,へテロナノ材料のような双晶間隔がナノオーダである 材料に対しては転位密度が極端に低い領域を表現すること はできない。本解析では円盤状の転位源形状を仮定し，あ る大きさの転位源を離散的に配置することによって,へテ 
ロナノ材料の初期状態を模擬する。既報 ${ }^{21)}$ と同様に, 位置 $x$ における初期転位密度 $\rho_{d 0}^{(\alpha)}$ を次式で与える。

$$
\rho_{d 0}^{(\alpha)}(\boldsymbol{x})=\sum_{i}^{n_{s}} \rho_{s 0}^{(\alpha)}\left\{-\frac{1}{2} \tanh \left(c \frac{\left|\boldsymbol{x}-\boldsymbol{\mu}^{(i)}\right|-l / 2}{l / 2}\right)+\frac{1}{2}\right\}
$$

ここで, $n_{s}$ は解析領域内の転位源の数, $\rho_{s 0}^{(\alpha)}$ は初期転位源密 度および $\mu^{(i)}$ は転位源の中心を示す位置べクトルである。 転位源の数 $n_{s}$ は次式で与えられる。

$$
n_{s}=\frac{2 d \rho_{t 0} A}{3 \pi l}
$$

ここで, $d$ は平均結晶粒径, $\rho_{t 0}$ は全初期転位密度および $A$ は解析モデルの面積である。また, 初期転位源密度 $\rho_{s 0}^{(\alpha)}$ は次 式のように求められる。

$$
\rho_{s 0}^{(\alpha)}=\frac{6}{d l}
$$

式（20）を式（19）に代入し整理すると全初期転位密度 $\rho_{t 0}$ が次式のように求められる。

$$
\rho_{t 0}=\rho_{s 0}^{(\alpha)} n_{s} \pi\left(\frac{l}{2}\right)^{2}
$$

本モデルを用いた結晶塑性シミュレーションの特徴とし て，転位源や粒界からの転位の放出やGN転位を介した転 位の隣接粒への伝播といった，超微細組織における転位挙 動を直接表現可能となっており，本報で対象としているよ うなナノオーダの組織を有する金属材料の微視的塑性変形 挙動を検討するのには適していると考えられる。

\section{4. 数値解析結果および考察}

\section{$4 \cdot 1$ 有限要素解析モデル}

本解析では FCC 構造を有するオーステナイト系ステン レス鋼を想定し，FCCの12すべり系を考慮した結晶塑性 シミュレーションを行った。用いた材料定数扣よび材料パ ラメータを Table 1 に示す。Burgersべクトルの大きさ $\widetilde{b}$, 横 弾性係数 $\mu$ および異方性弾性係数 $C_{11}, C_{12}$ および $C_{44}{ }^{25)}$ など の材料定数に関しては化学組成の近いステンレス鋼の值を 用い，参照すべり速度 $\dot{\gamma}_{0}$, 参照流れ応力 $\tau_{0}^{(\alpha)}$ ，ひずみ速度感 度指数 $m$, Peierls-Nabarro 応力に基づくせん断応力 $\tau_{P N}$, 結 晶粒界から転位が放出されるのに必要なせん断応力 $\tau_{G B}$, 可 動転位が結晶粒界を飛び越えるのに必要なせん断応力 $\tau_{G T}$, Frank-Read源に関するしきい值 $\rho_{s c}$ ，可動転位に関するしき い值 $\rho_{m r}$ および方位差に関するしきい值 $\phi_{r}$ といった実験で は測定が極めて困難な材料パラメータに関しては文献值 ${ }^{21)}$ を参考に決定し, 初期転位密度 $\rho_{0}^{(\alpha)}$, 転位の対消滅率 $k$, 蓄 積転位長さ $r$ ，転位源サイズ $l$ および数值定数 $a$ は実験で得
られた応力ーひずみ関係との比較により同定した。

$2 \cdot 1$ 節に示した強圧延を施したSUS316LN材の組織観 察結果に基づき，へテロナノ組織に見られる目玉状組織部 を簡素化して作製した有限要素解析モデルを Fig.4に示す。 Fig.4において左および中央の分布はNDおよびRDに対す る結晶方位を表し, 黒線は方位差 $15^{\circ}$ 以上の大角粒界に相 当する。解析モデルにおける $x$ 方向はNDと一致しており, $y$ 方向は RD と平行である。なお, 解析モデルにおける結晶 方位を $x$ 軸 (ND) に対して $90^{\circ}$ 回転させ，引張方向が TD と 一致するような方位分布を有する解析モデルも作製して 解析を行い，引張方向による変形挙動の差異を考察した。 実際には目玉状組織はTDに若干伸張した形状となってい る ${ }^{26)}$ が，そのアスペクト比にはばらつきがあり，また，そ の形状を圧延加工によって制御するのは困難である。そこ で本解析では，計算の簡単化のため形状の影響を取り除 き，圧延加工によって制御することが可能であると考えら れる双晶領域の体積分率, 双晶境界間隔およびラメラ間隔 あるいはせん断帯幅を変化させ，RD およびTDに対する引 張変形挙動を調査する。Fig.4の右の分布はある一つのす心゙ り系における初期の転位源の分布を表しており, 青色の領 域は転位源に相当する。転位源は各粒の中央に配置するよ うにし，どの粒に配置するかは無作為に選択した。双晶， せん断帯およびラメラ状組織の各境界を直線で近似し, 双 晶間およびラメラ状組織間の境界を $y$ 方向 $(\mathrm{RD}$ あるいは TD）と平行とした。解析モデルは計算時間の短縮のため, 2 次元の平面応力状態を仮定した。全方向に周期境界条件 を適用し, $x$ 方向に対する荷重が零になるように解析領域 の頂点を制御し, 公称ひずみが 0.05 となるまで $y$ 方向へ強

Table 1. Material constants and material parameters used in multiscale crystal plasticity simulation.

\begin{tabular}{c|c}
\hline Elastic shear modulus $\mu$ & $75.2 \mathrm{GPa}$ \\
\hline Anisotropic elastic modulus $C_{11}$ & $191.1 \mathrm{GPa}$ \\
\hline Anisotropic elastic modulus $C_{12}$ & $117.8 \mathrm{GPa}$ \\
\hline Anisotropic elastic modulus $C_{44}$ & $138.5 \mathrm{GPa}$ \\
\hline Magnitude of burgers vector $\widetilde{b}$ & $0.257 \mathrm{~nm}$ \\
\hline Referential slip rate $\dot{\gamma}_{0}$ & $0.001 \mathrm{~s}^{-1}$ \\
\hline Referential flow stress $\tau_{0}^{(\alpha)}$ & $1 \mathrm{MPa}$ \\
\hline Strain rate sensitivity $m$ & 0.005 \\
\hline Numerical number $a$ & 1 \\
\hline Critical shear stress based on Peierls-Nabarro stress $\tau_{P N}$ & $10 \mathrm{MPa}$ \\
\hline Minimum shear stress for dislocations released from \\
grain boundaries $\tau_{G B}$ & $3000 \mathrm{MPa}$ \\
\hline Minimum shear stress when dislocation traverse grain \\
boundaries $\tau_{G T}$ & $1000 \mathrm{MPa}$ \\
\hline Reference density of dislocation source $\rho_{s c}$ & $1.0 \times 10^{10} \mathrm{~m}^{-2}$ \\
\hline Reference mobile dislocation density $\rho_{m r}$ & $1.0 \times 10^{13} \mathrm{~m}^{-2}$ \\
\hline Threshold of misorientation $\phi_{r}$ & $3.0 \times 10^{7}$ \\
\hline Initial dislocation density $\rho_{0}^{(\alpha)}$ & $1.0 \times 10^{13} \mathrm{~m}^{-2}$ \\
\hline Annihilation ratio $k$ & $2.0 \times 10^{-14} \mathrm{~m}^{2}$ \\
\hline Mean length of remaining dislocation lines $r$ & $17.7 \mathrm{~nm}$ \\
\hline Size of dislocation source $l$ & $20 \mathrm{~nm}$ \\
\hline
\end{tabular}


制変位を与えて引張試験を模擬した。2・1節の測定結果に 基づき双晶境界間隔を $20 \mathrm{~nm}$ ，ラメラ状組織間隔を $100 \mathrm{~nm}$ およびせん断帯幅を $90 \mathrm{~nm}$ とした。双晶領域ではFCC金属 の2種類の双晶の結晶方位を双晶境界を境に交互に与え た。ラメラ状組織の境界は小角粒界であるため, 境界に囲 まれた各ラメラ状組織に測定した結晶方位から最大 $15^{\circ}$ の ゆらぎを持つ結晶方位をランダムに与えた。同様に，せん 断帯は微小なサブグレインによって構成されているため, せん断帯内の各要素に測定した結晶方位から最大 $15^{\circ}$ のゆ らぎを持つ結晶方位をランダムに与えた。解析モデルは三 角形要素を用いて，節点数 38756 および要素数 76670 に分 割した。

双晶境界間隔，ラメラ状組織間隔打よびせん断帯幅の影 響を考察するために, Fig.4に示す解析モデルに打ける双晶 境界間隔，ラメラ状組織間隔打よびせん断帯幅を変更して 有限要素解析モデルを作製した。双晶境界間隔 $d_{t}$ を $50 \mathrm{~nm}$, $100 \mathrm{~nm}$ ，ラメラ状組織間隔 $d_{l}$ を $250 \mathrm{~nm}, 500 \mathrm{~nm}$ およびせん 断帯幅 $d_{s}$ を $45 \mathrm{~nm}, 120 \mathrm{~nm}$ と変更し解析を行った。解析モ デルの節点数および要素数は Fig.4のものと同程度である。 また，実験では約 $57 \%$ もの双晶領域の面積率が計測されて おり ${ }^{26)}$ ，双晶領域の面積率は合金組成や圧延プロセスに依 存して幅広い分布を示すと考えられる。そこで, 変形双晶 領域の体積分率の影響を考察するために, Fig.5 (b) およ び (c) に示すような変形双晶領域が中心のみに存在し，そ の体積分率 $f_{t}$ が $4.2 \%, 18.8 \%$ となる解析モデルおよびFig. 5

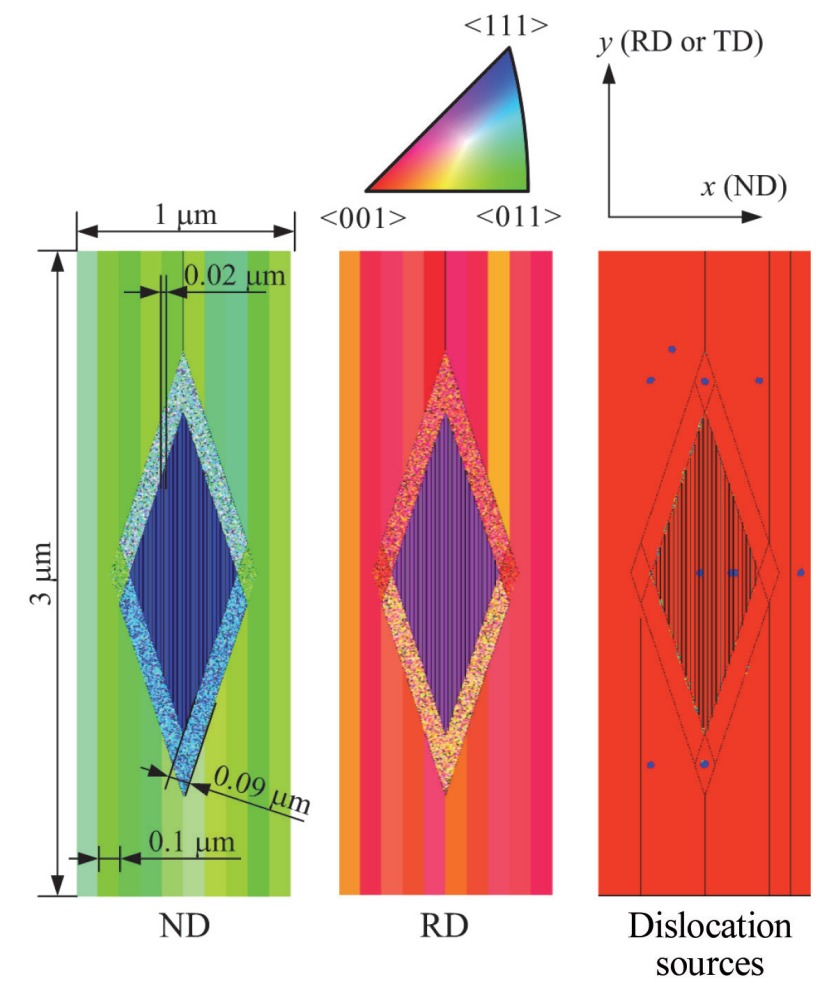

Fig. 4. Computational model of heterogeneous-nanostructure for multiscale crystal plasticity simulation. (Online version in color.) （d）から (f) に示す変形双晶領域が中心と四隅に存在し， その体積分率 $f_{t}$ が $25.0 \%, 40.1 \%, 70.6 \%$ となる解析モデル を作製し解析を行った。また，ラメラ状組織打よび変形双 晶のみ, すなわち, $f_{t}=0 \%, 100 \%$ の解析モデルも作製し解 析を行った。なお, 変形双晶領域の体積分率は, 解析モデ ル全体の面積に対する変形双晶の面積であり, Fig.4の解 析モデルの変形双晶の体積分率は $12.5 \%$ となる。この值は Fig.1で観察した目玉状組織に対する双晶の体積分率 10\% 前後に相当する。いずれの解析モデルもほぼ同サイズの三 角形要素を用いて分割した。

\section{$4 \cdot 2$ 引張方向による変形挙動の評価}

Fig.6に双晶領域の体積分率が $f_{t}=12.5 \%$ のときの張 方向が RD およびTDの場合の応力ーひずみ線図を示す。 ヤング率はそれぞれ引張方向が RDの場合 $143 \mathrm{GPa}$ 打よび $\mathrm{TD}$ の場合 $234 \mathrm{GPa}$ であり，実験で得られたヤング率 (RD： $177 \mathrm{GPa}$ ，TD：233 GPa）と近い值を示している。一方，0.2\% 耐力はそれぞれ引張方向が RDの場合 $2485 \mathrm{MPa}$ 扎よびTD の場合 $3009 \mathrm{MPa}$ であった。実験值 (RD：1411 MPa, TD： $1548 \mathrm{MPa})$ に対して本解析で得られた $0.2 \%$ 耐力は大きな 值を示した。なお，弾性率および $0.2 \%$ 耐力に関する考察に ついては双晶の体積分率の関係と併せて $4 \cdot 4$ 節で行う。本 解析では双晶領域に合わせて転位源のサイズをすべての領 域で $20 \mathrm{~nm}$ としているため, せん断帯やラメラ状組織領域 でも転位源の活動には非常に高い分解せん断応力が必要と される。双晶領域と比べて大きい転位源をこれらの領域で

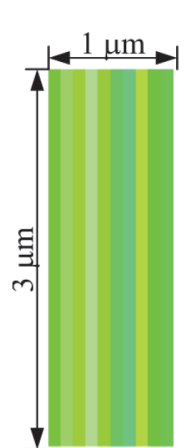

(a) $f_{t}=0 \%$

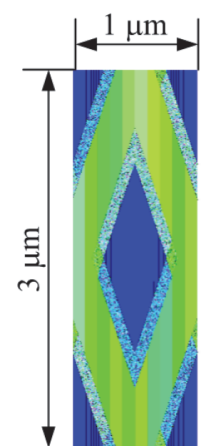

(d) $f_{t}=25.0 \%$

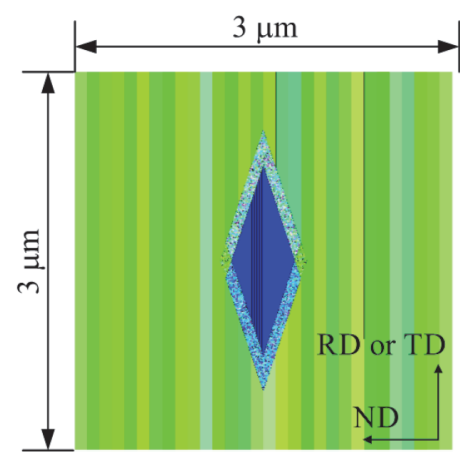

(b) $f_{t}=4.2 \%$

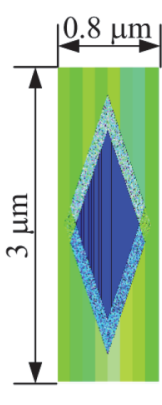

(c) $f_{t}=18.8 \%$

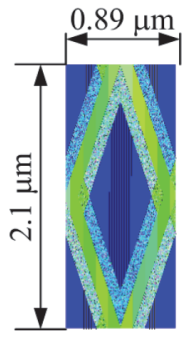

(e) $f_{t}=40.1 \%$

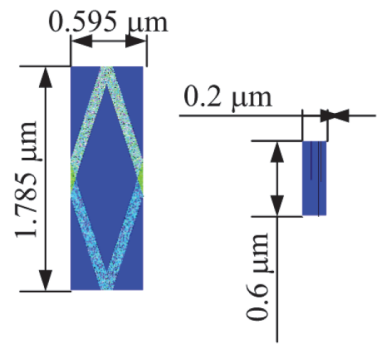

(f) $f_{t}=70.6 \%$ (g) $f_{t}=100 \%$

Fig. 5. Computational models with different volume fraction of deformation twin region. (Online version in color.) 
配置することによって, 実験で測定された程度の応力值を 示すものと考えられる。また，実験では結晶方位の違いに 起因して力学特性の異なる変形双晶, ラメラ状組織および せん断帯が不規則に並んでいるが, 本解析では局所的な組 織観察結果を基に周期境界条件を用いて各組織が規則的 に並んだ材料を表現したことに起因すると考えられる。さ らに，実験では方位の異なる変形双晶領域も観察されてお り ${ }^{20)}$ ，このような方位差も応力に差が生じた原因の一つと 考えられる。実験および解析における引張方向がTDに対 する $0.2 \%$ 耐力の值はRDに対する $0.2 \%$ 耐力のおよそ 1.10 倍および1.16倍であり良い一致を示した。引張方向が TD の場合の方が RDの場合よりヤング率および $0.2 \%$ 耐力が大

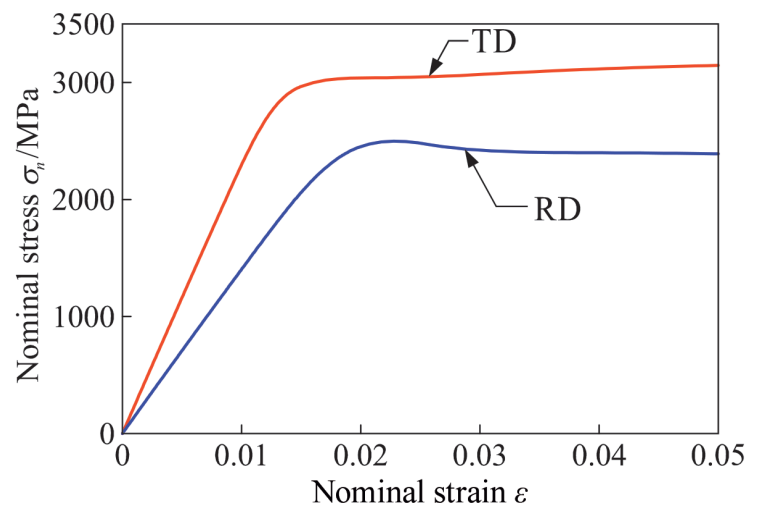

Fig. 6. Numerical stress-strain curves for RD tension and TD tension when the volume fraction of deformation twin region is $12.5 \%$. (Online version in color.)
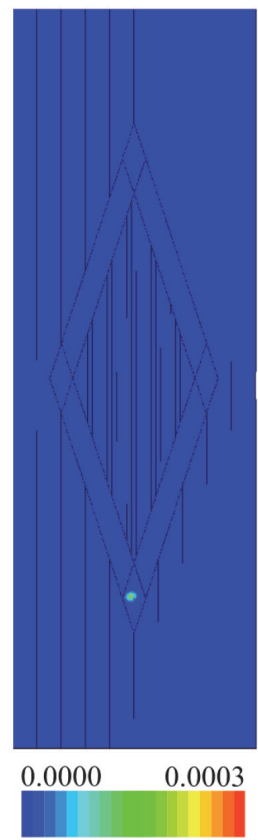

(a) $\varepsilon=0.01$

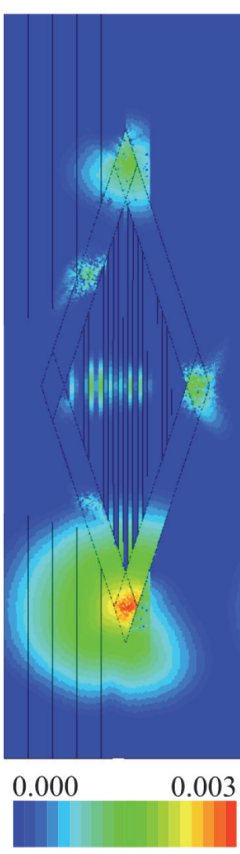

(b) $\varepsilon=0.015$

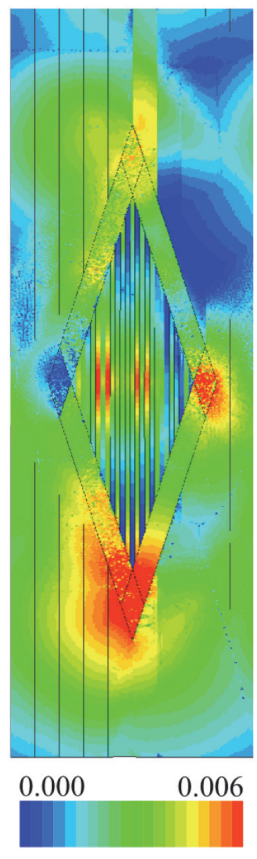

(c) $\varepsilon=0.02$
Fig. 7. Distribution of equivalent plastic strain when loading direction is parallel to $\mathrm{RD}$ and the volume fraction of deformation twin region is $12.5 \%$. (Online version in color.)
きくなり, 本解析手法を用いて局所的なへテロナノ組織に おける引張方向による変形挙動の差異の傾向は表現されて いることが確認できた。

Fig.7 およびFig.8に各公称ひずみ值のときの相当塑性ひ ずみの分布を示す。引張方向がRDの場合, 塑性変形は主 にせん断帯およびラメラ状組織で開始し, 変形双晶では塑 性ひずみの值は比較的小さい。一方, 引張方向が TDの場 合, 塑性変形はせん断帯およびラメラ状組織から開始する が, 変形双晶においても同様に塑性変形が進行する。変形 双晶の双晶間隔は $20 \mathrm{~nm}$ であり, 転位源が存在しない双晶 が多数存在する。変形双晶領域では引張方向に関係なく転 位源から塑性変形が開始するものの, 変形双晶領域内の塑 性変形挙動を比較すると, 引張方向が TDの場合は転位源 から開始した塑性変形が双晶境界を跨いで全体へ伝播する のに対し, 引張方向がRDの場合は他の双晶へ塑性変形が 伝播せず, 全体的に塑性ひずみが増大するのはさらに変形 が進行してからであった。双晶領域の塑性変形挙動, すな わちすべり系の活動状況について検討するため, Fig.5 (g) に示す $f_{t}=100 \%$ の解析モデルの中心に転位源を配置した 解析を行った。この際, すべてのすべり系が同等に活動可 能となるように，転位源をすべてのすべり系に配置した。 Fig.9に各引張方向に対する主すべり系のすべりの分布を 示す。引張方向が RDの場合, すべりは解析領域の中心, す なわち転位源の存在する双晶内で進展しいるものの, 双晶 境界を跨いだすべりの伝播は見られない。それに対し, 引 張方向が TDの場合は, 転位源から進展した塑性変形が双

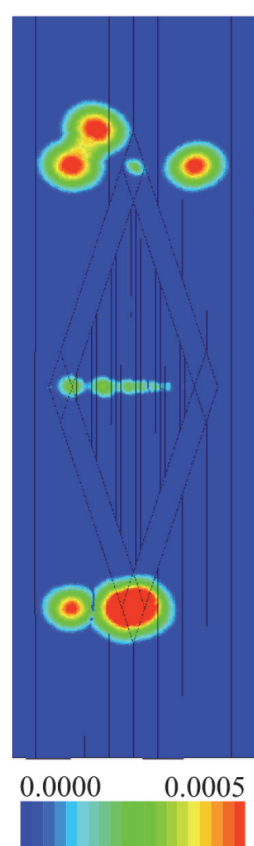

(a) $\varepsilon=0.01$

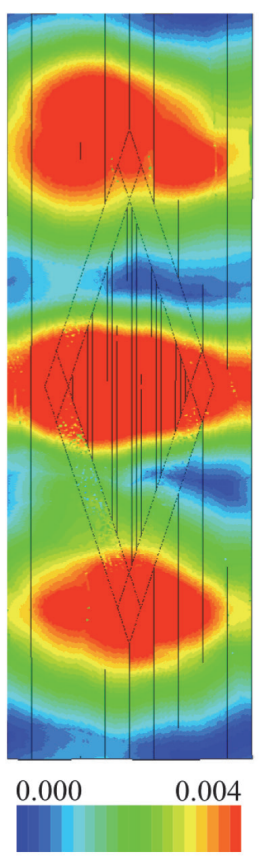

(b) $\varepsilon=0.015$

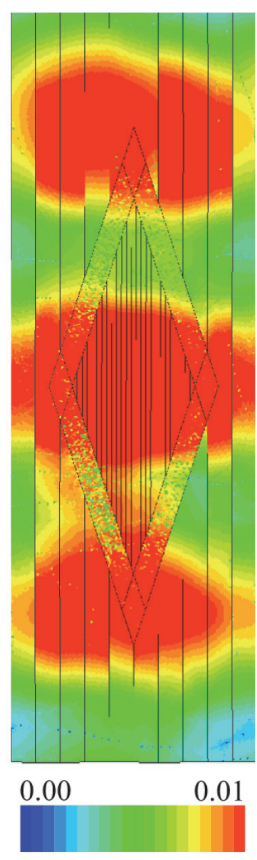

(c) $\varepsilon=0.02$
Fig. 8. Distribution of equivalent plastic strain when loading direction is parallel to TD and the volume fraction of deformation twin region is $12.5 \%$. (Online version in color.) 
晶境界を跨いで広がっていることが確認できる。同様の挙 動はFig.7およびFig.8にも見ることができる。Fig.10に各 双晶のすべり系に相当する Thompson四面体を示す。Fig.10 において, 太線で表された正三角形は双晶境界面と平行で ある。各引張方向に対する Schmid因子から，主すべり系と なり得るすべり系の数は引張方向が RD および $\mathrm{TD}$ の場合, それぞれ2つ打よび4つであり，Schmid因子の值はいずれ も 0.4082 であった。主すべり系のすべり方向を Fig.10の矢 印で示す。引張方向がRDの場合には，ある粒に打いて発 生した転位はすべり面やすべり方向が異なる隣接粒へと伝 播せず，粒内で塑性変形が完結してしまっている。それに 対し, 引張方向がTDの場合には主すべり系が4種類あり, すべり方向が一致しているすべり系が双晶境界を跨いで存 在することから, 発生した転位が容易に双晶境界を跨いで 伝播することが想定される。ただし，本解析では転位はあ

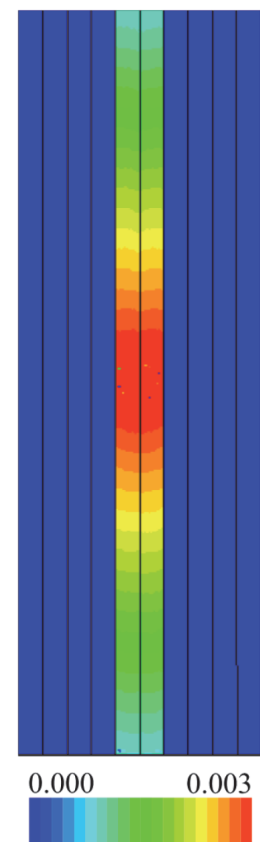

(a) $\mathrm{RD}$

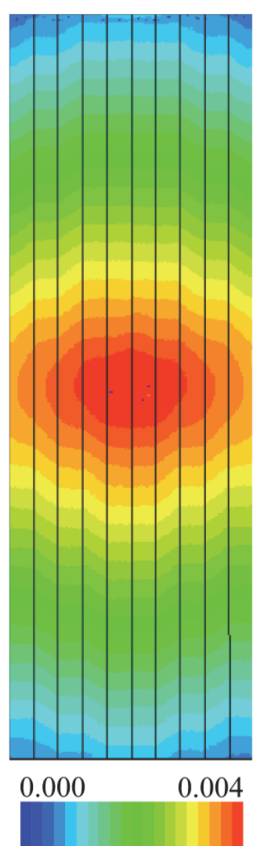

(b) TD
Fig. 9. Distributions of slip on the primary slip system when loading direction is parallel to (a) RD or (b) TD and the volume fraction of deformation twin region is $100 \%$. (Online version in color.)

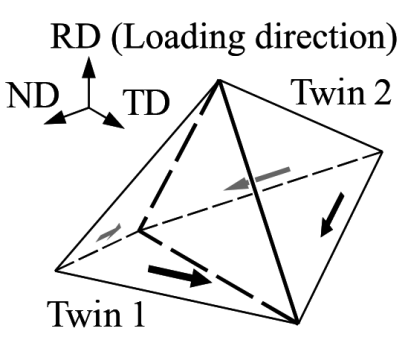

(a) $\mathrm{RD}$

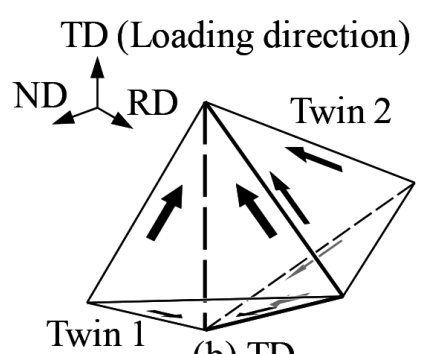

(b) TD
Fig. 10. Active slip systems in Thompson tetrahedra for deformation twin region when loading direction is parallel to (a) RD or (b) TD.
る一つのすべり系内でのみ活動するとしている。すべり系 には 1 から 12 まで番号を設定し, 設定した 12 のすべり系の 相対的な位置関係を保ちつつ, 隣接する双晶においては同 じ番号のすべり系のすべり方向とすべり面の法線方向が全 体的に最も近くなるように自動的にすべり系の初期配置を 決定している。そのため, 理想的にすべての転位が双晶境 界を跨いですべり方向・すべり面の近いすべり系へと伝 播するわけではないが，このような双晶の方位差の影響に よって引張方向に依存した塑性変形挙動の違いが生じ, 強 度の差が生じたのだと考えられる。一方, ラメラ状組織に おいては, ラメラ境界間隔を $100 \mathrm{~nm}$ としているため転位源 が組織内全体に存在し，ラメラ粒同士の方位も近いことか ら塑性変形がラメラ状組織内で全体的に進行しており,引 張方向による変形挙動の顕著な差異は見られなかった。

\section{$4 \cdot 3$ 双晶境界間隔,ラメラ境界間隔およびせん断帯幅の影響}

Fig. 11 に双晶境界間隔 $d_{t}$, ラメラ境界間隔 $d_{l}$ およびせん 断帯幅 $d_{s}$ を変化させた場合の $0.2 \%$ 耐力を示す。基準とな るFig.4の解析モデルに対する寸法には下線を引いてある。 ラメラ境界間隔の減少に伴い $0.2 \%$ 耐力は若干増加し, こ れは結晶粒微細化による強度上昇と考えられるが, その差 は小さくラメラ境界間隔の影響は小さいといえる。双晶境 界間隔の変化に伴って $0.2 \%$ 耐力は変化しているが, 相関 はあまり見られない。ナノオーダである双晶境界間隔が変 化すると, 双晶内に含まれる転位源の数が零と 1 で無作為 に変化してしまうため, 双晶境界間隔と $0.2 \%$ 耐力の関係 を本解析手法で求めることは難しい。本シミュレーション ではこれらの間隔は粒の幅に相当し, 粒ごとの変形挙動は 異なる。しかしながら, 双晶領域打よびラメラ状組織領域 のいずれも粒を複数含んでおり, これらの平均的挙動が巨 視的な強度として現れるため, 局所的な塑性変形挙動の差 が現れなかったのだと考えられる。一方, せん断帯幅の変 化に伴い $0.2 \%$ 耐力は大きく変化している。Fig.7に示すよ うに, 塑性変形はせん断帯から開始することから, せん断

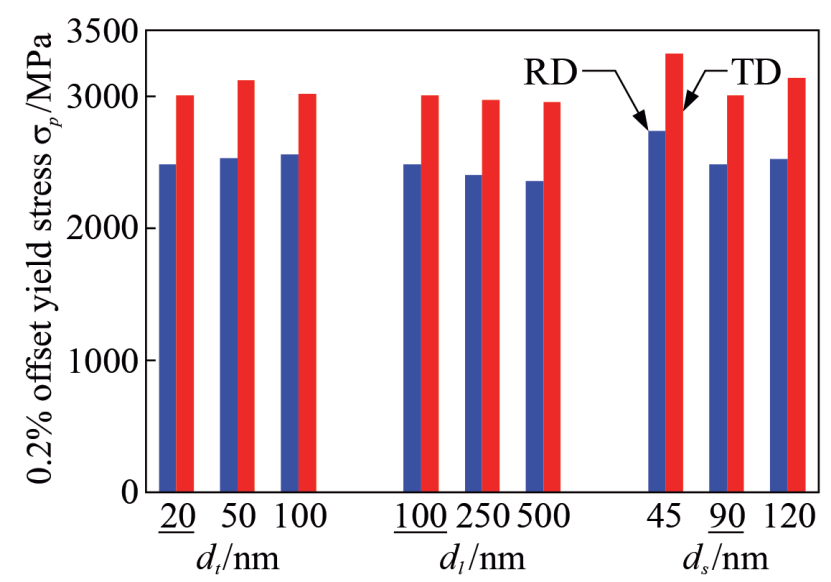

Fig. 11. Variation of $0.2 \%$ offset yield stress with different interspacings of twin boundaries and lamellar boundaries, and width of shear band. (Online version in color.) 
帯における降伏挙動が全体の降伏挙動に与える影響は比 較的大きいと考元られる。せん断帯内は小角粒界に囲まれ 結晶方位差がある多数の微細な領域で構成されており，そ の中で結晶のすべりを生じやすい結晶方位を持つ領域が 存在したため，せん断帯に打いて塑性変形が開始したと考 えられる。実際，せん断帯内の結晶方位を一様として解析 を行った場合には, Fig.4の解析モデルに対する $0.2 \%$ 耐力 の值は 1.13 倍へと上昇した。せん断帯幅の減少による $0.2 \%$ 耐力の上昇については，せん断帯幅の減少に伴い，結晶の すべりを生じやすい結晶方位を持つ領域の数が減少するた めであると考えられる。ただし，前述の通り本解析では初 期転位源を含まない領域が無作為に存在するため，せん断 帯幅と強度の相関は強くはない。以上のことから, 強度に おいてはせん断帯幅の影響は, 双晶境界間隔およびラメラ 境界間隔の影響と比較して大きいと言える。ただし，強度 の上昇率自体は大きくなく，せん断帯幅を圧延加工や熱処 理によって制御するのは困難であるため, 高強度化には有 用ではないと考えられる。

\section{$4 \cdot 4$ 変形双晶の体積分率の影響}

Fig.12に変形双晶の各体積分率におけるヤング率 $E$ およ び $0.2 \%$ 耐力 $\sigma_{p}$ を示す。いずれの双晶体積分率においても

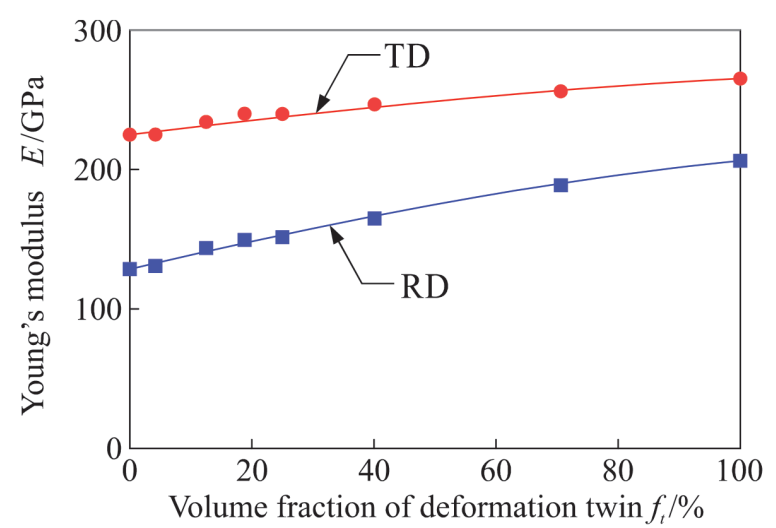

(a) Rigidness

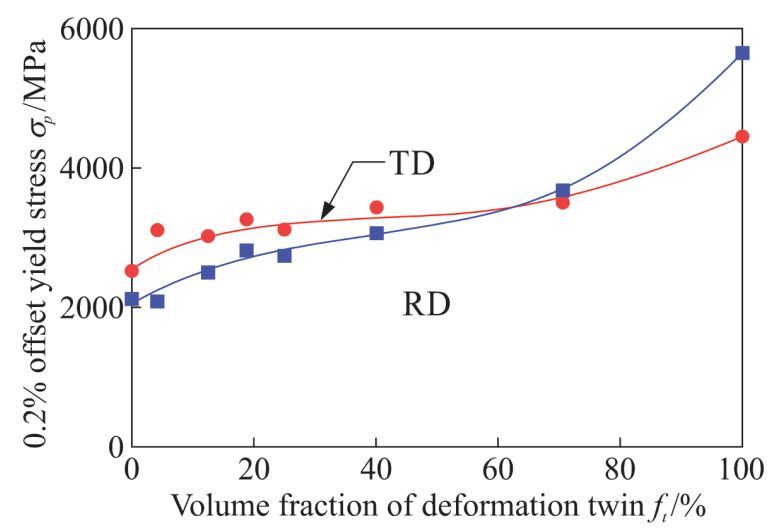

(b) Strength

Fig. 12. Increase of strength of severely cold-rolled stainless steels with increase of volume fraction of deformation twin region. (Online version in color.)
引張方向が TDの場合の方がヤング率の值は大きくなって いた。また，双晶領域の体積分率が大きいほどヤング率は 大きく，その変化率はTDと RDで異なり RDの方が大きい。 その方向きがほぼ一定であることから，巨視的なヤング率 は双晶領域打よびラメラ状組織領域の弾性異方性の影響 を受け，その值は，各領域の弾性率および双晶領域の体積 分率から決定されることがわかる。数值解析では体積分率 が 12.5\%であるのに対し, 実際の試験片は $10 \%$ 前後と観察 領域によってばらつきがあるため，また，今回解析で使用 した結晶方位, 特にラメラ状組織の結晶方位が狭い領域で 測定したものであるため，このような差が生じたと考えら れる。より広域での方位測定の結果を反映させた解析モデ ルを用いることで計算精度を向上させることができると 考えられる。一方, $0.2 \%$ 而力に関してはいずれの体積分率 に打いても引張方向がRDの場合は, 変形双晶領域内の塑 性ひずみは小さくラメラ状組織打よびせん断帯の塑性ひ ずみが大きくなるのに対し, 引張方向が TDの場合は変形 双晶領域でも塑性ひずみが大きくなっていた。すなわち, $f_{t}$ $=4.2 \%, 12.5 \%, 18.8 \%$ の解析モデルと $f_{t}=25.0 \%, 40.1 \%$, $70.6 \%$ の解析モデルでは変形双晶領域の配置に違いがある が，いずれの体積分率においても $f_{t}=12.5 \%$ の場合と同様 の変形挙動を示すといえる。Fig.10から変形双晶領域の体 積分率の増加に伴う $0.2 \%$ 耐力の増加が確認できる。これ は, $f_{t}=0 \%, 100 \%$ の $0.2 \%$ 耐力を比較しても明らかなよう に, ラメラ状組織より変形双晶領域の方が高強度であるこ とに起因する。双晶の強度のみを比較すると, 引張方向が $\mathrm{RD}$ の場合の方が高い。これは, 前述の通り, 双晶境界を跨 いだ転位伝播挙動の違いに起因する。いずれの引張方向の 場合もSchmid因子の值は同一であったことから，すべての 双晶領域に転位源が存在する場合に各粒の強度は計算上は 一致するが，転位の伝播が困難な引張方向が RDの場合は $\mathrm{TD}$ の場合と比べて強度が上昇する。一方，ラメラ状組織の 強度は引張方向が TDの場合の方が若干高い。ラメラ状組 織での塑性変形挙動に違いが見られなかったことから,こ の差は単に結晶方位の違いに起因するものであると考えら れる。そのため, 変形双晶の体積分率の増加に伴う $0.2 \%$ 而 力の増分はTDの場合の方が小さく, 変形双晶の体積分率 が小さい場合は引張方向が TDの場合の方が高強度だが, 変形双晶の体積分率が大きくなると引張方向が RDの場合 の方が高強度となる。以上のように, 強圧延誘起へテロナ ノ組織の強度は変形双晶領域の体積分率の増加に伴い向上 するため, 圧延により変形双晶を高密度に導入することに よってさらなる高強度化が期待される。へテロナノ組織の 塑性変形挙動は領域によって異なり, 塑性変形の伝播が困 難な双晶領域の存在によって, 予想を超えた高強度化が実 現したものであると考えられる。 


\section{5. 結言}

本研究では, 強圧延を施したオーステナイト系ステンレ ス鋼 SUS316LNの強度に及ぼす微視的影響因子を明らかに するため, 微細組織の観察および応力ーひずみ関係の測定 を行い，へテロナノ組織および結晶方位の情報を導入した 結晶塑性有限要素解析を用いて, 強度に及ぼす因子につい て調査した。その結果，以下の知見を得た。

(1) ラメラ状組織では強度の差は結晶方位の影響によるも のであり, その差は小さい。一方, 双晶領域の強度の差 は双晶境界を跨いだ転位の伝播挙動の違いによるもの であり，結晶方位の影響以上の強度差が生じる。

(2) せん断帯から塑性変形が開始するため, せん断帯に含 まれるサブグレインの数および転位源の数が強度に与 える影響は大きく, 双晶境界間隔およびラメラ境界間 隔は各領域に対して十分に小さいため強度に及ぼす影 響は小さい。

（3）ラメラ状組織と比較して変形双晶領域の強度が高いが, ヘテロナノ組織の塑性変形挙動は領域によって異な り, 塑性変形の伝播が困難な双晶領域の存在によって, 予想を超えた高強度化が実現したものであると考えら れる。

\section{謝辞}

本研究は, 科学技術振興機構 (JST) による産学共創基 礎基盤研究「革新的構造用金属材料創製を目指したへテロ 構造制御に基づく新指導原理の構築」およびJSPS科研費 16H06059の支援を受けて行われたものである。また, 本研 究の遂行および本論文の執筆にあたり, 大学院生 (当時) の魚路知生氏の協力を得た。ここに感謝の意を表する。

\section{文献}

1 ) Z.Horita, D.J.Smith, M.Furukawa, M.Nemoto, R.Z.Valiev and T.G.Langdo: J. Mater. Res., 11(1996), 1880.

2 ) A.Belyakov, W.Gao, H.Miura and T.Sakai: Metall. Mater. Trans. A, 29(1998), 2957.

3 ) Y.Saito, N.Tsuji, H.Utsunomiya, T.Sakai and R.G.Hong: Scr. Mater, 39(1998), 1221.

4 ) N.Tsuji: Tetsu-to-Hagané, 88(2002), 359.

5 ) X.Huang, N.Hansen and N.Tsuji: Science, 312(2006), 249.

6 ) Y.Saito, H.Utsunomiya, N.Tsuji and T.Sakai: Acta Mater, 47(1999), 579.

7 ) N.Tsuji, Y.Ito, Y.Saito and Y.Minamino: Scr. Mater., 47(2002), 893.

8 ) C.Y.Yu, P.W.Kao and C.P.Chang: Acta Mater, 53(2005), 4019.

9 ) H.Mughrabi: Proc. Eng., 2(2010), 3.

10) Y.Mine and Z.Horita: Mater. Trans., 53(2012), 773.

11) T.Nishizaki, S.Lee, Z.Horita, T.Sasaki and N.Kobayashi: Physica $C$, 493(2013), 132.

12) T.Morikawa, T.Moronaga and K.Higashida: Tetsu-to-Hagané, 91(2005), 834

13) Y.Nakao and H.Miura: Mater. Sci. Eng. A, 528(2011), 1310.

14) H.Miura and R.Morita: J. Jpn. Inst. Copp., 52(2013), 121.

15) O.Grassel, L.Kruger, G.Frommeyer and L.W.Meyer: Int. J. Plast., 16(2000), 1391.

16) L.Lu, Y.Shen, X.Chen, L.Qian and K.Lu: Science, 304(2004), 422.

17) L.Lu, X.Chen, X.Huang and K.Lu: Science, 323(2009), 607.

18) O.Bouaziz, S.Allain, C.P.Scott, P.Cugy and D.Barbier: Curr. Opin. Solid State Mater. Sci., 15(2011), 141.

19) H.Miura, M.Kobayashi, Y.Todaka, C.Watanabe, Y.Aoyagi, N.Sugiura and N.Yoshinaga: Scr. Mater., 133(2017), 33.

20) H.Miura, M.Kobayashi, Y.Todaka, C.Watanabe and Y.Aoyagi: J. Jpn. Inst. Met. Mater, 81(2017), 536.

21) Y.Aoyagi, T.Tsuru and T.Shimokawa: Int. J. Plast., 55(2014), 43.

22) J.Pan and J.R.Rice: Int. J. Solids Struct., 19(1983), 973.

23) T.Ohashi: Philos. Mag. A, 70(1994), 793.

24) Y.Aoyagi and K.Shizawa: Int. J. Plast., 23(2007), 1022.

25) M.Kikuchi: Trans. JIM, 12(1971), 417.

26) C.Watanabe, S.Kobayashi, Y.Aoyagi, Y.Todaka, M.Kobayashi, N.Sugiura, N.Yoshinaga and H.Miura: Tetsu-to-Hagané, 105(2019), 254. 